\title{
Metode Pembelajaran Role Playing Dalam Meningkatkan Keaktifan Dan Hasil Belajar IPA Pada Materi Pertumbuhan Makhluk Hidup
}

\author{
Bernadeta Juminten $^{1)}$ bernadeta.juminten67@gmail.com \\ Tiurlina Siregar $^{2)}$ tiurlina.siregar@yahoo.com \\ ${ }^{1}$ SD YPPK Santo Petrus Nabire \\ ${ }^{2}$ Program Studi Magister Pendidikan IPA UNCEN
}

\begin{abstract}
The purpose of this study was to determine the increase in activeness and learning outcomes of students by using role playing learning methods in mahkul living growth material at SD YPPK St. Peter Nabire. The method used is quasi perimental. The results of the study increased the learning activeness of science in the material of growth of living creatures by $44.4 \%$ and $n$-Gain on average by using role playing learning methods of 0.9 with a high category. Learning outcomes after learning by using the role playing method in class VI of SD YPPK St. Peter.
\end{abstract}

Key words : Role Playing Method, Students Favorable and Study Output.

Tujuan penelitian ini untuk mengetahui peningkatan keaktifan dan hasil belajar peserta didik dengan menggunakan metode pembelajaran role playing pada materi pertumbuhan mahkul hidup di SD YPPK Santo Petrus Nabire. Metode yang digunakan adalah quasi perimental. Hasil penelitian Peningkatan keaktifan belajar IPA pada materi pertumbuhan mahkluk hidup sebesar $44,4 \%$ dan $n$-Gain rata-rata dengan menggunakan metode pembelajaran role playing sebesar 0,9 dengan kategori tinggi. Hasil belajar setelah dilakukan pembelajaran dengan menggunakan metode role playing di kelas VI SD YPPK Santo Petrus.

Kata kunci: Metode Bermain Peran, Menguntungkan Siswa dan Hasil Belajar

\section{PENDAHULUAN}

Peningkatan kualitas pendidikan yang optimal di sekolah dapat ditempuh dengan berbagai cara. Salah satunya adalah variasi model pembelajaran. Selama ini model pembelajaran yang diterapkan di sekolah adalah model pembelajaran konvensional. Pembelajaran akan lebih menyenangkan apabila seorang guru ada yang aktif. Strategi pembelajaran yang digunakan guru aktif dan bervariasi, tidak monoton, senantiasa disesuaikan dengan materi pelajaran, situasi kondisi, serta proses pembelajarannya. Pembelajaran yang menyenangkan dapat dilakukan dengan berbagai 
model. Salah satunya adalah model pembelajaran bermain peran.

Upaya meningkatkan keaktifan belajar peserta didik merupakan tantangan yang selalu dihadapi oleh setiap orang yang berkecimpung dalam profesi keguruan dan pendidikan. Banyak upaya yang telah dilakukan dan banyak pula keberhasilan yang telah dicapai, meskipun keberhasilan itu belum sepenuhnya memberikan kepuasan bagi masyarakat dan pendidik, sehingga sangat menuntut renungan, pemikiran, dan kerja keras orang-orang yang berkecimpung di dalam dunia pendidikan untuk memecahkan masalah yang dihadapi.

Keberhasilan proses belajar mengajar sangat ditentukan oleh seorang guru yang melakukan transfer ilmu melalui proses pembelajarannya. Dalam hal ini, strategi pembelajaran menjadi penting dalam proses belajar mengajar tersebut. Kemampuan guru dalam memilih metode yang relevan dengan tujuan dan materi pembelajaran merupakan kunci keberhasilan dalam pencapaian prestasi belajar siswa.

Keberhasilan pencapaian kompetensi satu mata pelajaran bergantung kepada beberapa aspek. Salah satu aspek yang sangat mempengaruhi adalah bagaimana cara seorang guru dalam melaksanakan pembelajaran. Kecenderungan pembelajaran saat ini masih berpusat pada guru dengan bercerita atau berceramah. Siswa kurang terlibat aktif dalam proses pembelajaran. Akibatnya tingkat pemahaman siswa terhadap materi pelajaran rendah. Di samping itu media pembelajaran jarang digunakan dalam proses belajar mengajar, sehingga menjadi kurang bermakna.

Permasalahan yang dihadapi dalam pelaksanaan kegiatan pembelajaran IPA pada SD YPPK Santo Petrus di kelas VI adalah tingkat keberhasilan siswa dalam menempuh KKM yang ditetapkan sekolah yaitu 6,0 tidak tercapai. Kurang lebih $70 \%$ hasil belajar siswa di bawah KKM. Yang menjadi substansi penelitian ini adalah tidak efektifnya kegiatan pembelajaran pada materi pertumbuhan makhluk hidup oleh guru karena seringnya guru menggunakan metode konvensional. Dengan metode ceramah siswa tidak terlibat aktif dan cenderung bosan, sementara guru menjelaskan di depan kelas mirid-murid bermain saja, bahkan mengganggu teman lainnya sehingga suasana kelas cenderung ribut. Keaktifan belajar murid $60 \%$ tidak aktif. Sehingga hasil belajar kurang memuaskan. 


\section{METODE PENELITIAN}

Metode yang digunakan dalam penelitian ini adalah quasi eksperimental. Dalam penelitian quasi eksperimental ini, terdapat kelompok kelas eskperimen dan kelompok kelas kontrol. Dalam desain penelitian ini, kedua kelas diberi pretest dengan test yang sama. Kelas eksperimen diberi perlakuan dengan menggunakan metode pembelajaran role playing, sedangkan kelas kontrol adalah kelas lain yang diberi pembelajaran dengan model konvensional. Pada awal dan akhir pembelajaran kedua kelas diberi test yang sama. Hasil kedua test, baik kelas eksperimen maupun kelas kontrol dibandingkan (diuji perbedaannya), sehingga desain penelitiannya sebagai berikut:

$\begin{array}{llll}\text { E : } & \text { O1 } & \text { X1 } & \text { O2 } \\ \text { K : } & \text { O3 } & \text { X2 } & \text { O4 }\end{array}$

E Menyatakan Kelas Eksperimen, $\mathrm{K}$ menyatakan Pembelajaran dengan Role Playing, X1, menyatakan Pembelajaran dengan Role Playing, X2 menyatakan Pembelajaran dengan model konvensional ( metode ceramah ), O1 menyatakan Pretest pada kelas eksperimen, $\mathrm{O} 2$ menyatakan Postest pada kelas eksperimen, O3 menyatakan Pretest pada kelas kontrol dan O4 menyatakan Postest pada kelas kontrol

Sampel yang digunakan dalam penelitian ini berjumlah 45 orang siswa di SD YPPK Santo Petrus Nabire, yang terdiri dari kelas VI/A sebagai kelas eksperimen sebanyak 23 siswa, dan kelas VI/B sebagai kelas kontrol sebanyak 22 siswa. Kelas VI/A diajar dengan menggunakan metode role playing, sedangkan kelas VI/B menggunakan model pembelajaran konvensional ( metode ceramah).

\section{HASIL DAN PEMBAHASAN}

Metode pembelajaran role playing terhadap keaktifan belajar IPA pada materi pertumbuhan mahkluk hidup peserta didik kelas VI SD YPPK Santo Petrus Nabire.

Data keaktifan peserta didik diperoleh dari peserta didik dengan menggunakan angket. Pengisian angket dilakukan oleh semua peserta didik kelas eksperimen maupun kelas kontrol. Tanggapan peserta didik dikelompokkan ke dalam lima kategori yaitu: (1) Sangat Setuju, (2) Setuju, (3) Kurang Setuju, (4) Tidak Setuju, (5) Setuju (Tabel 1): 
Tabel 1 Karakteristik Keaktifan Peserta didik

\begin{tabular}{|c|l|c|c|}
\hline No. & \multicolumn{1}{|c|}{ Keaktifan } & Frekuensi & Prosentasi (\%) \\
\hline 1 & Sangat setuju & 20 & 44,4 \\
\hline 2 & Setuju & 15 & 33,3 \\
\hline 3 & Kurang setuju & 10 & 22,2 \\
\hline 4 & Tidak setuju & 5 & 0,11 \\
\hline 5 & Sangat tidak setuju & 0 & 0 \\
\hline \multicolumn{2}{|r|}{ Jumlah } & 45 & 100 \\
\hline
\end{tabular}

Sumber: Data Primer Penelitian

Berdasarkan tabel 1 menunjukkan bahwa sebagian besar responden sebesar 44,4 \% masuk kategori cukup aktif dala, mengikuti pembelajaran dengan menggunakan metode role playing.

Hasil belajar peserta didik mata pelajaran IPA pada materi pertumbuhan makhluk hidup diketahui melalui pretest (tes awal) dan postest (tes akhir). Secara umum hasil belajar peserta didik meningkat setelah menggunakan metode role playing.

Penelitian yang dilakukan oleh Ibnu Sina, (2008) tentang penerapan strategi pembelajaran role playing dengan $\quad \mathrm{CD}$ interaktif untuk meningkatkan motivasi belajar peserta didik kelas VII SMP Negeri 10 Surakarta memiliki hasil yang sama dengan penelitian ini. Hasil penelitian sebelumnya menunjukkan rata-rat indikator aspek adanya daya penggerak dari dalam peserta didik untuk melakukan kegiatan pembelajaran $68,48 \%$.

Berdasarkan uji statistik homogenitas dengan SPSS 16.0 diperoleh data keaktifan peserta didik Sig 0,081 > 0,05 maka data homogen (tabel 4.9). Uji beda sig 0,04<0,05, maka Ha diterima. Berarti ada pengaruh metode role playing terhadap keaktifan.

Salah satu faktor yang mempengaruhi hasil belajar adalah keaktifan, keaktifan peserta didik sangat diperlukan dalam proses belajar mengajar. Dengan adanya keaktifan yang tinggi yang tinggi maka belajar akan berjalan baik serta menghasilkan hasil belajar yang maksimal. metode role playing dapat membuat peserta didik menjadi aktif dalam mengikuti kegiatan belajar. Model pembelajaran dapat meningkatkan keaktifan belajar (Adriana Ardi, 2016:24) n-Gain ratarata pada kelas eksperimen dan kelas kontrol ditunjukkan pada Tabel 2 berikut ini: 
Tabel 2 perbandaningan n-Gain rata-rata kelas Eksperimen dan kelas Kontrol

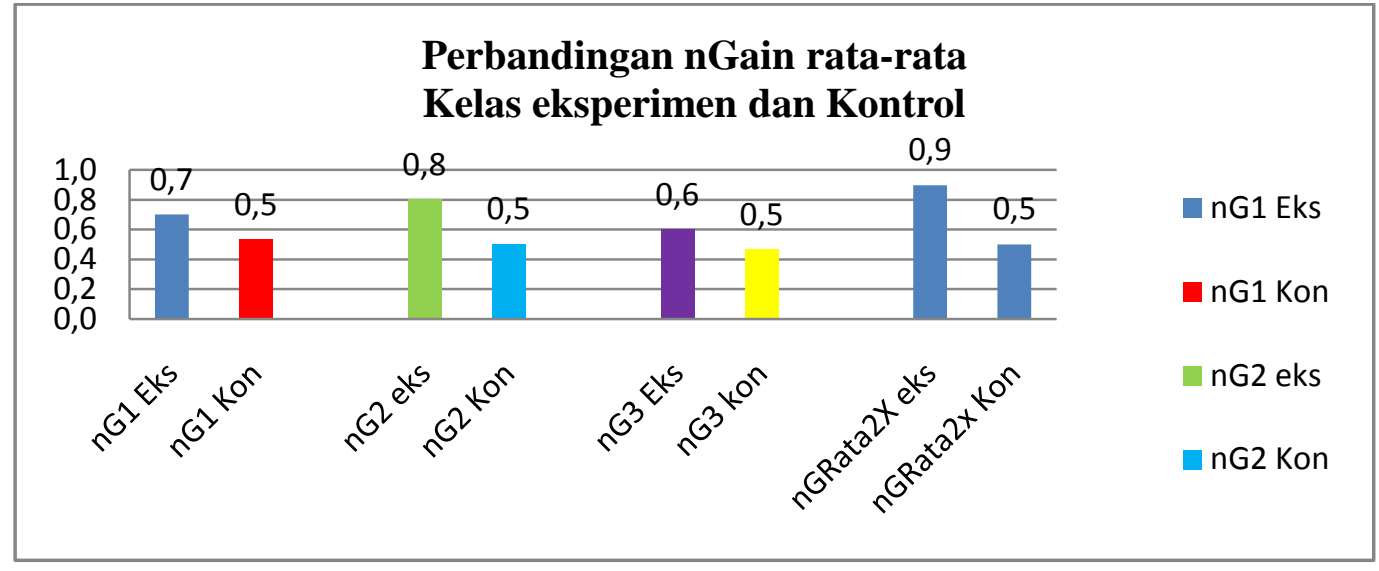

(Sugiyono, 2013)

Berdasarkan Tabel 2 menunjukkan bahwa n-Gain rata-rata hasil belajar peserta didik setelah mengikuti pembelajaran secara umum mengalami peningkatan. Untuk kelas eksperimen termasuk tinggi yaitu 0,9 , sedangkan kelas kontrol termasuk sedang yaitu 0,5. Hal ini terjadi bukan karena kebetulan tetapi karena kedua kelas memang mendapat perlakuan yang berbeda, dengan menggunakan model pembelajaran yang berbeda pula.

Metode role playing terhadap hasil belajar IPA pada materi pertumbuhan mahkluk hidup.

Hasil belajar peserta didik IPA pada materi pertumbuhan makhluk hidup diketahui melalui pretest (tes awal) dan postest (tes akhir). Secara umum hasil belajar peserta didik meningkat setelah menggunakan metode role playing.

Hasil analisis rata-rata $\mathrm{n}$-Gain hasil belajar peserta didik setelah mengikuti pembelajaran secara umum mengalami peningkatan. Untuk kelas eksperimen termasuk tinggi yaitu 0,9, sedangkan kelas kontrol termasuk sedang yaitu 0,5 .

Hal ini tentunya tidak terjadi secara kebetulan. Karena perbedaan perlakuan yang diberikan kepada kedua kelas. Berdasarkan uji statistik dengan SPSS 16.0 diperoleh data untuk RPP 1 Sig yang diperoleh $0,101>0,05$ maka data homogen (tabel 4.6). Uji beda sig $0,00<0,05$, maka Ha diterima.

Berdasarkan uji statistik dengan SPSS 16.0 diperoleh data untuk RPP 2 Sig yang diperoleh 0,482>0,05 maka data homogen (tabel 4.7). Uji beda sig $0,00<0,05$, maka Ha diterima.

Berdasarkan uji statistik homogenitas dengan SPSS 16.0 diperoleh data untuk RPP 3 Sig yang diperoleh $0,081>0,05$ maka data homogen (tabel 4.8). Uji beda sig 0,04 $<0,05$, maka Ha diterima. 
Ada pengaruh hasil belajar peserta didik yang diajar dengan metode role playing juga mengalami peningkatan, dibandingkan peserta didik yang diajar dengan menggunakan metode ceramah atau konvensional. Hal ini dapat dilihat dengan diterimanya Ha yang berarti bahwa hasil belajar peserta didik yang diajar dengan metode role playing lebih tinggi dari pada peserta didik yang diajar dengan metode ceramah. Dengan demikian, Ho ditolak dan peneliti dapat menguji kebenaran hipotesis, yaitu metode role playing terhadap hasil belajar IPA peserta didik kelas VI pada SD YPPK Santo Petrus nabire terdapat pengaruh yang signifikan. Selain itu, metode role playing menjadikan peserta didik terlibat aktif dalam pembelajaran, sehingga pembelajaran tidak didominasi oleh guru. Metode role playing juga memberikan suasana baru yang menyenangkan, dan hal ini merupakan salah satu motivasi sehingga peserta didik lebih antusias dalam mengikuti proses pembelajaran. Dengan aktifnya peserta didik dan suasana yang menyenangkan dalam proses pembelajaran, pemahaman peserta didik terhadap konsep pertumbuhan makhluk hidup meningkat sehingga hasil belajar peserta didik pun lebih meningkat.
Penelitian yang dilakukan Cahya Khaerani, 2010. "Pengaruh Metode Role Playing Terhadap Hasil belajar Biologi Pada Konsep Gerak Pada Tumbuhan, pada Universitas Islam Negeri Syarif Hidayatullah Jakarta. Dari hasil penelitiannya diperoleh nilai $t$ hitung sebesar 6,61 sedangkan $\mathrm{t}$ tabel pada taraf signifikan 0,05 sebesar 1,99 atau $\mathrm{t}$ hitung $>\mathrm{t}$ tabel. Maka dapat disimpulkan bahwa $\mathrm{Ha}$ yang menyatakan ada pengaruh metode role playing terhadap hasil belajar biologi peserta didik diterima atau disetujui. Hal ini menunjukkan bahwa penggunaan metode role playing membawa pengaruh yang signifikan terhadap hasil belajar biologi peserta didik.

Penerapan metode role playing pada kelas eksperimen sealma penelitian dilaksanakan membantu meningkatkan motifasi dan keaktifan belajar peserta didik. Meningkatnya hasil belajar IPA materi pertumbuhan makhluk hidup pada penelitian ini juga sesuai dengan penelitian yang relevan yang menunjukkan adanya peningkatan metode role playing terhadap hasil belajar, yaitu skripsi salah satunya penelitian Cahya Khaerani. Hasil penelitian Cahya Khaerani menunjukkan bahwa hasil belajar biologi kelompok yang menggunakan 
metode role playing lebih tinggi dari hasil belajar peserta didik yang menggunakan metode ceramah.

\section{SIMPULAN DAN SARAN}

\section{SIMPULAN}

Peningkatan keaktifan belajar IPA pada materi pertumbuhan mahkluk hidup di kelas VI SD YPPK Santo Petrus Nabire sebesar $44,4 \%$ dan nGain rata-rata dengan menggunakan metode pembelajaran role playing sebesar 0,9 dengan kategori tinggi.

\section{SARAN}

Manajemen waktu yang baik dalam penerapan setiap metode pembelajaran perlu diperhatatikan, khususnya metode role playing akan memberikan dampak yang positif pula terhadap hasil belajar yang ingin dicapai.

\section{DAFTAR PUSTAKA}

Adriana Ardi, 2016, Pengaruh Penerapan Model Pembelajaran Kooperatif dengan Tipe Role
Playing terhadap Minat dan Hasil Belajar IPA pada Materi Makhluk Hidup dan Lingkungan Siswa Kelas IV SD Inpres Dekai Kabupaten Yahukimo, Jurnal Ilmu Pendidikan Indonesia, 4(1) 24-33.

Cahya Khaerani, Pengaruh Metode

Role Playing Terhadap Hasil

Belajar Biologi Peserta didik

Pada Konsep Gerak Pada

Tumbuhan. Skripsi, Universitas

Islam Syarif Hidayatullah Jakarta, 2009.

Ibnu Sina, (2008) Implementasi Model pembelajaran Role Playing

Didasari Analisis Swot Pada Materi Peluang, Tesis, Program Studi Matematika, Universitas Negeri Semarang,

Sugiyono, 2013. Metode Penelitian Pendidikan (Pendekatan Kuantitatif, Kualitatif, dan $R$ \& D), Bandung : Alfabeta 